\title{
Pengaruh Distribusi Pendapatan dan Daya Serap Tenaga Kerja Pada Industri Kecil di Kota Jambi
}

Oleh:

\author{
*) Muhammad Sabyan \\ **)Dosen Tetap STIE Muhaammadiyah Jambi
}

\begin{abstract}
Abstrak
Sektor industri mempunyai peranan penting dalam menuju kemajuan dalam sebuah perekonomian, ini dikarenakan sektor industri diyakini dapat memimpin sektor-sektor dalam menciptakan nilai tambah yang dibanding produk-produk sektor lain. Dengan menggunakan analisis CES maka dapat dilihat bahwa sektor industrialisasi dan pembangunan industri merupakan salah satu jalur untuk meningkatkan kesejahteraan rakyat dalam arti peningkatan pendapatan. Searah dengan perkembangan industri, ini mencerminkan peningkatan daya serap tenaga kerja, maka diharapkan juga terjadi pendistribusian pendapatan atas pemilik modal dengan tenaga kerja yang lebih merata.
\end{abstract}

\section{Kata kunci: industrialisasi, CES, Pendapatan, Tenaga Kerja}

\section{Pendahuluan}

Proses pembangunan seringkali dikaitkan dengan proses industrialisasi. Proses industrialisasi dan pembangunan industri sebenarnya merupakan satu jalur kegiatan untuk meningkatkan kesejahteraan rakyat dalam arti tingkat hidup yang lebih maju maupun taraf hidup yang lebih bermutu. Menurut Arsyad (2007) Pembangunan industri merupakan suatu fungsi dari tujuan pokok kesejahteraan rakyat, bukan merupakan kegiatan yang mandiri untuk hanya sekedar mencapai fisik saja.

Sektor industri diyakini sebagai sektor yang dapat memimpin sektor-sektor lain dalam sebuah perekonomian menuju kemajuan. Dalam bukunya yang di tulis oleh Dumairy (Dumairy, 2009) Produk-produk industrial selalu memiliki "dasar tukar" (term of trade) yang tinggi atau lebih menguntungkan serta menciptakan nilai tambah yang besar disbanding produk-produk sektor lain.

Sejalan dengan hal tersebut, maka peran sektor industri pengolahan semakin penting, sehingga sektor industri pengolahan mempunyai peranan sebagai sektor pemimpin (Leading Sector) di sektor industri secara umum.Keadaan tersebut juga berlaku di Kota Jambi. Hal ini dapat dilihat dari kontribusi sektor industri terhadap Produk Domestik Regional Bruto (PDRB) seperti terlihat dalam Tabel 1.1 berikut 
Tabel 1. Distribusi Persentase PDRB menurut Lapangan Usaha Atas Dasar Harga Berlaku Di Kota Jambi Tahun 2010-2012

\begin{tabular}{|l|c|c|c|}
\hline Lapangan Usaha & $\begin{array}{c}\mathbf{2 0 1 0} \\
\mathbf{( \% )}\end{array}$ & $\begin{array}{c}\mathbf{2 0 1 1} \\
\mathbf{( \% )}\end{array}$ & $\begin{array}{c}\mathbf{2 0 1 2} \\
(\mathbf{\%})\end{array}$ \\
\hline Pertanian & 1,48 & 1,43 & 1,36 \\
\hline Pertambangan dan Penggalian & 8,68 & 8,04 & 7,35 \\
\hline Industri Pengolahan & 15,40 & 15,44 & 15,48 \\
\hline Listrik dan Air Bersih & 2,87 & 2,83 & 2,84 \\
\hline Bangunan & 6,33 & 6,48 & 6,59 \\
\hline Perdagangan, Hotel dan Restoran & 24,72 & 25,16 & 26,04 \\
\hline Angkutan dan Komunikasi & 17,85 & 18,09 & 18,05 \\
\hline Keuangan, Sewa dan Jasa Perusahaan & 9,16 & 9,46 & 9,78 \\
\hline Jasa-jasa & 13,51 & 13,07 & 12,51 \\
\hline PDRB & 100 & 100 & 100 \\
\hline
\end{tabular}

Sumber : BPS Kota Jambi

Dari table 1. di atas dapat diketahui bahwa pertumbuhan kontribusi sektor industri pengolahan cukup baik terhadap PDRB di mana pada tahun 2010 pangsanya sebesar $15,40 \%$ pada tahun 2011 sebesar 15,44\% dan pada tahun 2012 sebesar 15,48\%. Dari angka tersebut maka dapat diketahui bahwa kontribusi sektor industri pengolahan di Kota Jambi cukup baik di samping sektor Perdagangan, Hotel dan Restoran.

Menurut Sukirno (2009) penanaman modal atau investasi dalam teori adalah pengeluaran-pengeluaran untuk membeli barang-barang modal dan peralatan produksi dengan tujuan untuk mengganti dan terutama menambah barang-barang modal dalam perekonomian yang akan digunakan untuk memproduksi barang dan jasa di masa depan. Dengan adanya penanaman modal di Kota Jambi maka pemerintah atau pihak swasta dapat mengembangkan usaha atau menambah unit-unit usaha, dengan pengembangan usaha atau penambahan unitunit usaha akan membutuhkan banyak tenaga kerja. Dengan demikian penambahan modal dapat mengurangi masalah pengangguran.

Sumber daya yang digunakan untuk menghasilkan barang dan jasa terdiri dari berbagai faktor seperti tenaga kerja, tanah dan modal termasuk mesin-mesin, peralatan, bahan mentah, tenaga listrik, kemajuan teknologi dan lain-lain.Namun diantara semua faktor tersebut, faktor sumber daya manusia memegang peranan utama dalam meningkatkan produktivitas karena alat produksi dan teknologi pada hakekatnya adalah hasil karya manusia. Oleh karena itu, disamping produktivitas tanah dan modal yang biasanya ditonjolkan dan menjadi pusat perhatian adalah produktivitas tenaga kerja.Produktivitas tenaga kerja di 
pengaruhi oleh beberapa faktor, baik yang berhubungan dengan tenaga kerja itu sendiri, maupun yang berhubungan dengan lingkungan dan kebijakan pemerintah (J.Ravianto. 2008).

MenurutSimanjuntak (2007) dan Handoko (2008), Penyerapan tenaga kerja di sektor industri kecil dipengaruhi oleh faktor internal dan eksternal dari tiap-tiap unit usahanya. Secara internal dipengaruhi oleh tingkat upah, produktivitas tenaga kerja,modal(teknologi), dan pengeluaran non upah lainnya. Sedangkan secara eksternal dipengaruhi oleh tingkat pertumbuhan ekonomi, tingkat inflasi, pengangguran dan tingkat bunga.

Searah dengan perkembangan jumlah industri kecil yang ada dan peningkatan investasi serta peningkatan daya serap tenaga kerja, maka diharapkan juga terjadi pendistribusian pendapatan atas pemilik modal dengan tenaga kerja yang lebih merata.Namun demikian, pencapaian atas beberapa hal tersebut secara bersamaan adalah suatu hal yang sulit diupayakan.

Kondisi ini justru menimbulkan kekhawatiran akan terjadinya substitusi modal terhadap tenaga kerja. Substitusi modal terhadap tenaga kerja tersebut dapat mempengaruhi daya serap tenaga kerja pada industri kecil (Embang dan Tricahyono, 2009). Sehingga pada akhirnya akan dapat mempengaruhi pendistribusian pendapatan antar pemilik modal dengan tenaga kerja.

\section{Metode Penelitian}

\section{Jenis dan Sumber Data}

Jenis data yang digunkan dalam penelitian ini adalah data primer yang langsung diambil dari objek penelitian.

Data yang digunakan dalam penelitian ini dikumpulkan melalui dua sumber, data primer dan data sekunder

Jenis data primer yang diperlukan untuk analisis penelitian ini meliputi:

1. Jumlah tenaga kerja yang di serap

2. Upah tenaga kerja tiap unit usaha

3. Nilai produksi yang dihasilkan tiap unit usaha

4. Biaya bahan baku tiap unit usaha

Sedangkan data sekunder yang dikumpulkan untuk mendukung dalam analisis penelitian ini meliputi Data yang di dapatkan dari kantor Badan Pusat Statistik Provinsi Jambi, BPS Kota Jambi, Kantor Desperindag Jambi, Kantor Desperindag Kota Jambi, hasil 
penelitian dan laporan-laporan hasil penelitian terdahulu dan publikasi ilmiah lainnya yang ada kaitannya dengan penelitian.

\section{Metode Pengumpulan Data}

Sumber data yang digunakan adalah industri kecil yang berkedudukan dan beroperasi di daerah Kota Jambi.Adapun jenis industri kecil yang dijadikan objek adalah industri. Hasil pertanian dan kehutanan, industri Aneka, Industri Kimia dan Industri Mesin, Logam dan Elektronika.

\section{Metode Analisis}

Dalam penelitian ini, untuk menjawab semua permasalahan diatas. Penulis menggunakan analisis CES .Model tersebut harus bisa menganalisa fenomena yang di teliti untuk menjadikan sebagai dasar untuk menganalisis fenomena tersebut

a. Untuk menganalisis permasalahan dalam penelitian ini, yaitu distribusi Pendapatan antara pemilik Modal dengan tenaga kerja serta pada industri kecil maka digunakan formula sebagai berikut :

$$
Q=A\left[\alpha K^{-p}+(1-\alpha) L^{-p}\right]^{v p}
$$

Keterangan :

$\mathrm{Q}=$ Produksi yang dihasilkan

$\mathrm{K}=$ Modal

$\mathrm{L}=$ Tenaga kerja

$\mathrm{A}=$ Parameter elastisitas subtitusi

$\mathrm{P}=$ Parameter elastisitas subtitusi

$\alpha=$ Parameter distribusi pendapatan

$\mu=$ Parameter skala hasil

Dengan begitu kita dapat memperoleh parameter $\sigma, \alpha, \rho, \mu$ dan A melalui estimasi dua tahap. Tahap pertama di buat untuk mendapatkan nilai parameter $\sigma, \alpha$ dan $\rho$ yaitu dengan mentransformulasikan persamaan (2.14) ke dalam bentuk Linear :

$\operatorname{Ln}\left(\frac{K}{L}\right)=\frac{1}{1+\rho} \operatorname{Ln}\left(\frac{\alpha}{1-\alpha}\right)+\frac{1}{1+\rho} \operatorname{Ln}\left(\frac{w}{r}\right)$

L 
Adapun pada persamaan (2.9) $\sigma=-$ maka persamaan (3.1) menjadi :

$$
1+p
$$

$\operatorname{Ln}\left(\frac{K}{L}\right)=\sigma \operatorname{Ln}\left(\frac{\alpha}{1-\alpha}\right) \sigma \operatorname{Ln}\left(\frac{w}{r}\right)$

Adapun asumsiøLn maka persamaan (3.2) secara sederhana akan berbentuk

$\operatorname{Ln}\left(\frac{K}{L}\right)=c+\sigma \operatorname{Ln}\left(\frac{w}{r}\right)$

Untuk persamaan (3.3) akan di ketahui parameter $\sigma$, sehingga selanjutnya :

$$
\begin{aligned}
& \rho=\frac{1-\sigma}{\sigma} \\
& \alpha=\frac{\operatorname{antiLn}\left(\frac{c}{\sigma}\right)}{\operatorname{antiLn}\left(\frac{c}{\rho}\right)+1}
\end{aligned}
$$

b. Untuk mengetahui hasil analisis permasalahan kedua, yang menyangkut dengan pengaruh tingkat perubahan penggunaan modal terhadap tingkat perubahan daya setiap tenaga kerja digunakan rumusan sebagai berikut:

$\mathrm{V}=\left[\alpha K^{-p}+(1-\alpha) L^{-p}\right]^{-1 / p}$

Tahap selanjutnya parameter $\alpha$ dan $\mathrm{p}$ yang didapati pada tahap pertama disubtitusikan ke dalam (persamaan 2.4), sehingga diperoleh persamaan :

$\mathrm{Q}=\mathrm{A} \mathrm{V}^{\mu}$

Persamaan (3.5) di masukan ke dalam bentuk linear, sehingga diperoleh bentuk:

$\mathrm{LnQ}=\mathrm{LnA}+\mu \mathrm{LnV}$

Hasil dari persamaan (3.6) memberitahukan bahwa dengan itu semua fungsi produksi CES telah didapati dalam membuat estimasi fungsi produksi CES.

Untuk memperoleh kevaliditasan dari analisis yang diteliti maka akan kita uji dengan pengujian statistik: Pertama, untuk menguji keberartian masing-masing koefisien regresi (partial test) maka digunakan t-tes

$$
\text { thitung }=\frac{\beta^{i}}{\sqrt{S^{2} \beta_{i}}}
$$

Keterangan: 
$\beta_{i}=$ koefisien regresi ke i

$S^{2}=$ Varians

Dengan kesimpulan :

1. $\mathbf{t}_{\text {hitung }}=\mathbf{t}_{\text {tabel }}$ : variable bebas secara sendiri-sendiri tidak berpengaruh nyata terhadap variable terikat.

2. $\mathbf{t}_{\text {hitung }}=\mathbf{t}_{\text {tabel }}$ : variable bebas secara sendiri-sendiri berpengaruh nyata terhadapt variable terikat.

Kedua , untuk mencari tingkat keberartian semua variabel bebas terhadap variabel terikat maka dilakukan uji F (Overall test) :

$\mathrm{F}_{\text {hitung }}=\frac{E M S(\text { Explainedm eanSqaure })}{R M S(\operatorname{Re} \text { sedualMean Square })}$

Dengan pembanding $\mathrm{F}_{\text {tabel }}=\mathrm{F}(0,01$ s.d $0,25, \mathrm{~V} 1, \mathrm{~V} 2)$

Keterangan : V1 $=\mathrm{k}-1$

$$
\begin{aligned}
& \mathrm{V} 2=\mathrm{n}-\mathrm{k} \text { dan } \mathrm{k}=\text { banyaknya variable } \\
& \mathrm{n}=\text { jumlah data }
\end{aligned}
$$

Maka didapati kesimpulan menjadi:

1. $\mathbf{F}_{\text {hitung }}=\mathbf{F}$ tabel $:$ semua variable bebas secara bersama-sama tidak mempengaruhi variable terikat. Ini bermakna bahwa model yang digunakan tidak tepat.

2. $\quad \mathbf{F}_{\text {hitung }}=\mathbf{F}$ tabel $:$ semua variable bebas secara bersama-sama mempengaruhi varibel terikat. Ini bermakna model yang digunakan tepat

Dengan mempertimbangkan pengestimasian model yang terbentuk adalah dalam bentuk

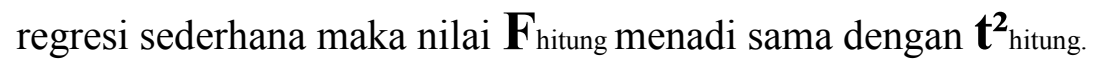

\section{Pembahasan}

Untuk lebih terperinci hubungan tingkat modal dan tingkat produksi pada industri kecil sampel dapat kita lihat pada tabel 2 di bawah ini.

\begin{tabular}{|c|c|c|c|c|}
\hline \multirow[b]{2}{*}{ Tingkat Modal } & \multicolumn{3}{|c|}{ Tingkat Produksi } & \multirow[b]{2}{*}{ Jumlah } \\
\hline & $\begin{array}{c}\text { Rendah } \\
8 \text { juta }-52 \text { Juta }\end{array}$ & $\begin{array}{c}\text { Sedang } \\
53 \text { Juta-97 Juta }\end{array}$ & $\begin{array}{c}\text { Tinggi } \\
\text { 98 Juta- } 142 \text { Juta }\end{array}$ & \\
\hline $\begin{array}{l}\text { Rendah } \\
1 \text { Juta- } 51 \text { Juta }\end{array}$ & 56 & 12 & - & 68 \\
\hline $\begin{array}{l}\text { Sedang } \\
52 \text { Juta - } 102 \text { Juta }\end{array}$ & 2 & 4 & - & 6 \\
\hline
\end{tabular}

Tabel 2. Hubungan Tingkat Modal dan Tingkat Produksi Pada Industri Kecil Sampel 


\begin{tabular}{|c|c|c|c|c|}
\hline $\begin{array}{l}\text { Tinggi } \\
\text { 103 Juta- 153 Juta }\end{array}$ & - & - & 1 & 1 \\
\hline Jumlah & 58 & 16 & 1 & 75 \\
\hline
\end{tabular}

Dari data tersebut di atas kita dapat melihat bahwa 74,66\% (56 industri kecil) dari 75 industri kecil sampel berada pada taraf hasil produksi yang tergolong rendah. Dan dapat dilihat juga hanya di temukan $1,33 \%$ (1 industri kecil) mempunyai produktifitas yang tergolong tinggi. Dari data produksi industri kecil sampel tersebut bisa disimpulkan bahwa rata-rata industri kecil di kota Jambi dapat menghasilkan Rp 37,130 juta per tahun.Faktor tersebut tidak terlepas dari sisi tingkat modal, didapati sekitar 90,66\% (68 industri kecil) dari industri kecil sampel memiliki modal tergolong rendah dalam hal klasifikasi yang dilakukan ini dan hanya $1,33 \%$ ( 1 industri kecil) yang memiliki modal tinggi, dengan tingkat modal ratarata $\operatorname{Rp} 20,28$ juta per industri kecil sampel

Untuk menunjang produktifitas tenaga kerja, upah merupakan salah satu faktor yang penting untuk di kedepankan. Dari tingkat upah pada industri sampel tidak ditemukan kesamaan dalam penggajian nya. Dari hasil penelitian yang dilakukan, upah yang di dapati oleh pekerja pada industri sampel berada pada kisaran Rp. 300.000,- per bulan sampai dengan Rp. 1.000.000,- per bulan dengan rata-rata per bulan nya berkisar Rp 750.000,-. Kalau di bandingkan dengan upah minimum yang di tentukan oleh Pemerintah Provinsi Jambi yang berkisar Rp 1.200.000,- per bulan maka itu bisa di katakan cukup bagi mereka.

Tabel 3. Tingkat Upah Tenaga Kerja Per Jenis Industri Kecil Sampel

\begin{tabular}{|l|c|c|c|c|}
\hline \multirow{2}{*}{ Jenis Industri } & \multicolumn{2}{|c|}{ Tingkat Upah per Tahun ( Ribuan Rupiah ) } & \multirow{2}{*}{ Jumlah } \\
\cline { 2 - 5 } & Rp.350- Rp. 500 & Rp. 600- Rp.800 & Rp. 850-Rp.1.000 & 28 \\
\hline $\begin{array}{l}\text { Industri Hasil Pertanian } \\
\text { dan Kehutanan }\end{array}$ & 22 & 3 & 3 & 22 \\
\hline Industri Aneka & 3 & 18 & 1 & 2 \\
\hline Industri Kimia & - & 12 & - & 13 \\
\hline $\begin{array}{l}\text { Industri Mesin Logam } \\
\text { dan Elektronik }\end{array}$ & 7 & 6 & - & 75 \\
\hline \multicolumn{1}{|c|}{ Jumlah } & 32 & 39 & 4 & \\
\hline
\end{tabular}

Dari data mengenai industri sampel, maka akan kita dapati hasil hasil estimasi data tersebut melalui dua tahap fungsi produksi CES. Dari persamaan regresi pada estimasi tahap pertama akan didapati hasil sebagai berikut : 
$\operatorname{Ln}(\mathrm{K} / \mathrm{L})=13,770+0,42 \operatorname{Ln}(\mathrm{w} / \mathrm{r})$

$\mathrm{t}_{\text {hitung }}=11.799$

$\mathrm{F}_{\text {hitung }}=286$

rSquare $\quad=0,04$

Hasil yang didapati dari persamaan regresi memberitahuakan bahwa nilai parameter nya menjadi :

$\sigma=0,42$

$$
\begin{aligned}
& \rho=\frac{1-0,4}{0,4}=1,3809 \\
& \alpha=\frac{\mathrm{a} \quad \mathrm{L}\left(\begin{array}{c}
1,3 \\
0,4
\end{array}\right)}{\mathrm{a} \quad \mathrm{L}\left(\begin{array}{c}
1,3 \\
0,4
\end{array}\right)+1}=0,999 \\
& (1-\alpha)=(1-0,999)=0,0001
\end{aligned}
$$

Untuk mengetahui nilai yang didapati dari parameter estimasi tahap kedua, sebelum nya kita lakukan dulu uji kelayakan model hasil estimasi. Uji kelayakan menggunakan Uji t dan Uji F

Hasil nya didapati bahwa $\alpha=0,01$ diketahui $\mathrm{t}$ hitung $(11,80)>\mathrm{t}$ tabel $(2,38)$ dan $\mathrm{F}_{\text {hitung }}(286)>\mathrm{F}$ tabel $(3,95)$. Dapat di diketahui bahwa variabel independent pada persamaan regresi estimasi tahap satu mempunyai pengaruh yang sangat nyata terhadap variabel dependent.

Hasil yang didapati pada regresi estimasi tahap pertama diketahui nilai $\mathrm{r}$ squere $=$ 0,04. Bisa dilihat bahwa variable independent memiliki kemampuan sebesar 4\% dalam menjelaskan variasi perubahan variabel dependent pada model. $96 \%$ sisa nya variasi perubahannya dipengaruhi oleh faktor lain.

Dari statistik pengujian yang dilakukan bisa didapati bahwa bahwa persamaan regresi dari hasil estimasi satu cukup valid digunakan untuk analisis lebih lanjut. Berdasarkan hal tersebut maka dilakukan estimasi tahap dua, yaitu dengan memasukkan parameter estimasi tahap satu ke dalam persamaan, sehingga menjadi:

$$
\mathrm{V}=\left[0,9999 K^{1,3809}+0,001 L^{1,3809}\right]^{-1 / 1,3809}
$$

Dengan memasukkan nilai $\mathrm{K}$ dan $\mathrm{L}$ dari setiap industri kecil sampel akan diperoleh nilai $\mathrm{V}$, yang kemudian disubstitusikan kembali kedalam fungsi produksi. Melalui 
transformasi ke dalam bentuk linear maka diperoleh hasil regresi estimasi tahap kedua, yaitu sebagai berikut:

$\begin{array}{ll}\mathrm{L}_{\mathrm{n}} \mathrm{Q}=11,620+ & 0,40 \mathrm{~L}_{\mathrm{n}} \mathrm{V} \\ \mathrm{t}_{\text {hitung }} & =4,14 \\ \mathrm{~F}_{\text {hitung }} & =17,2 \\ \text { rSquare } & =0,02\end{array}$

Dengan berakhirnya persamaan regresi dari estimasi yang kedua tersebut, maka di ketahui bahwa nilai parameter estimasi keseluruhan data telah lengkap. Tetapi sebelumnya akan dilakukan dahuluuji kelayakan model terhadap persamaan (5.3) melalui Uji t dan Uji F.

Untuk hasil $\alpha=0,01$ dapat di ketahui bahwa $\mathrm{t}_{\text {hitung }}(4,14)>\mathrm{t}_{\text {tabel }}(2,38)$ dan $\mathrm{F}_{\text {hitung }}$ $(17,2)>F_{\text {tabel }}(3,95)$. Dari hasil tersebut menunjukan bahwa variabel independent pada persamaan (5.3) secara statistik dapat melakukan pengaruh yang nyata terhadap variabel dependent. Sedangkan nilai $\mathrm{r}$ square $=0,02$. Data tersebut mengatakan bahwa variabel independent dari persamaan regresi hasil estimasi tahap dua mampu menjelaskan variasi dari perubahan variabel dependent sebesar 2\%, sedangkan sisanya sebesar 98\% dijelaskan oleh faktor lainnya.

Dari penggabungan kedua tahap estimasi fungsi produksi CES industri kecil, dan dari data hitungan statistik model estimasi yang dilakukan dapat dikatakan bahwa penelitian itu layak untuk dianalisis, dan dengan itu bisa dikatakan bahwa semua nilai parameter telah selesai di proses, selanjutnya akan dijabarkan dalam interprestasi atas nilai parameter yang di peroleh:

1. Untuk nilai parameter subtitusi yang didapati $\sigma=0,42$ dan $\rho=1,3809$, ini menunjukan bahwa tingkat elastisitas substitusi antara modal dan tenaga kerja adalah relatif kecil dari satu atau in elastis. Untuk itu maka, bila terjadi peningkatan biaya faktor modal sebesar $1 \%$ hal tersebut akan meningkatkan jumlah tenaga kerja sebesar 0,42\%. Dapat dikatakan bahwa hal tersebut relatif mudah mensubstitusi faktor produksi modal dengan tenaga kerja atau pun sebaliknya, sambil tetap mempertahankan tingkat output yang tetap. Hasil tersebut menunjukan bahwa industri kecil di kota Jambi memiliki daya serap tenaga kerja yang relatif sedang 
2. Sedangkan nilai parameter $A=11,620$. Itu mengindikasikan bahwa bila terjadi peningkatan pada faktor produksi sebesar satu unit maka akan meningkatkan produksi sebesar 11,620satuan. Dari hitungan tersebut bisa kita simpulkan bahwa industri kecil sampel cukup efisien.

3. Untuk parameter distribusi $\alpha=4,2785$. Mengindikasikan bahwa sebesar $4,3 \%$ sektor pendapatan industri kecil diterima oleh pemilik modal,95,7\% sisa nya di dapatkan dari tenaga kerja.

Untuk mengkaji lebih jauh,nilai elastisitas substitusi $\sigma=0,0001$ menunjukan bahwa dalam tingkat perubahan faktor produksi $(\mathrm{K} / \mathrm{L})$ sebesar 1\% akan membuat MTRS sebesar 1,0627\% (persamaan 2.8). indikator nya bahwa perubahan MRTS dan rasio intensitas faktor $(\mathrm{K} / \mathrm{L})$ terjadi pada tingkatan output tertentu, dengan begitu MRTS yang merupakan kenaikan relatif produktivitas marginal tenaga kerja terhadap modal, bisa mempengaruhi rasio intesnsitas faktor cenderung meningkat. Pada kondisi ini berarti industri bersifat padat modal (capital intensive).

Melihat tingkat industri yang padat modal maka mudah substitusi antara modal dengan tenaga kerja disebabkan tingkat modal lebih tinggi dari setandar upah tenaga kerja. Dalam keadaan elastis tersebut bisa dikatakan terjadi kenaikan biaya modal sebesar $1 \%$ (menunjukan juga peningkatan pada rasio harga input $\mathrm{w} / \mathrm{r}$ sebesar $1 \%$ ) dengan itu dapat meningkatkan tenaga kerja kurang dari $1 \%$ atau hanya $0,0001 \%$ (atau meningkatkan intensitas faktor K/L sebesar 0,0001\%), sehingga wL/rK menjadi naik (industri menjadi lebih padat modal). Dari deskripsi ini dapat kita intrpretasikan bahwa daya serap tenaga kerja pada industri kecil di Kota Jambi relatif cukup

Dengan tingkat industri yang elastis dan padat modal maka memberi konsekuensi pada lebih rendahnya tingkat produktivitas marginal tenaga kerja dari padat modal. Sehingga menurut Salvatore (2008)akan menjadikan industri lebih efisien dan hal ini ternyata ditemui pada industri kecil sampel, yang menunjukkan tingkat efisiensi $A=11,20$. Lebih lanjut menurut Clague (2009)tingkat efisiensi kecil yang demikian lebih menggambarkan tingkat kemampuan (skill) dan tingkat optimasi penggunaan tenaga kerja yang tersedia pada industri kecil.

Konsekuensi lebih jauh dari kondisi industri yang relatif padat modal adalah distribusi pendapatan yang relatif besar diterima oleh pemilik modal dibandingkan tenaga kerja. Dari 
hasil analisis, hal ini ditunjukkan dengan parameter distribusi $\mathrm{a}=4,2785$, yang berarti $42,78 \%$ tingkat pendapatan yang dihasilkan industri kecil diterima pemilik modal

\section{Kesimpulan Dan Saran}

\section{Kesimpulan}

1. Koefisien elastisitas substitusi antara modal dan tenaga kerja pada industri kecil di Kota Jambi adalah $\sigma=0,42$ atau bersifat inelastis . Ini berarti relatif sulitnya mensubstitusi faktor produksi modal dengan tenaga kerja sambil tetap mempertahankan tingkat loutput. Bila terjadi peningkatan pada biaya modal sebesar $1 \%$, industri kecil hanya mampu meningkatakan penyerapatan tenaga kerja sebesar 0,42\%. Kondisi ini mengindiikasikan daya serap tenaga kerja industri kecil di Kota Jambi relatif rendah. Hal ini merupakan implikasi dari teknik produksi industri kecil yang cenderung padat modal (capital intensive labor saving) yang terindikasi dari besarnya nilai rata-rata intensitas faktor $(\mathrm{K} / \mathrm{L})$ industri kecil.

2. Tingkat efisiensi industri kecil sampel di Kota Jambi adalah sebesar $A=11,620$. Ini berarti bila tejadi peningkatan pada faktor produksi sebesar satu unit satuan maka akan meningkatkan produksi sebesar 11,620 satuan.

3. Koefisien distribusi industri kecil sampel adalah $a=0,999$ hal ini menunjukkan bahwa 99,99\% bagian pendapatan yang dihasilkan industri kecil diterima oleh pemilik modal, sedangkan $0,1 \%$ diterima oleh tenaga kerja. Ini berarti tinggi bagian pendapatan yang diterima pemilik modal dibandingkan yang diterima tenaga kerja pada industri kecil di Kota Jambi.

Saran

Berdasarkan hasil analisis dan kesimpulan yang diperoleh maka dapat disarankan halhal berikut kepada:

1. Para pemerhati ekonomi lebih menekuni dan mendalami kajian-kajian penelitian yang berkaitan mengenai faktor daya serap tenaga kerja,tingkat efisiensi dan distribusi pendapatan dalam industri kecil yang terdapat di kota Jambi sebagai bahan acuan untuk masukan bagi instansi dan lembaga- lembaga ataupun mereka yang membutuhkan informasi tentang industri kecil di Kota Jambi . 
Sebagai identifikasi awal, dalam ruang lingkup analisis yang telah dilakukan, dapat diidentifikasikan beberapa faktor yang mempengaruhi daya serap tenaga kerja, tingkat efisiensi dan distribusi pendapatan pada industri kecil.Tekhnik produksi yang digunakan oleh industri kecil diduga merupakan faktor utama yang mempengaruhi daya serap tenaga kerja. Indikator yang berkenaan dengan tekhnik produksi yang digunakan adalah laju substitusi antar faktor input. Dimana tingkat kemudahan substitusi antar faktor itu sendiri dipengaruhi oleh harga input. Ini berarti perkembangan tingkat harga faktor input (tingkat upah atau bunga modal) akan menentukan daya serap tenga kerja. Selain itu tentu saja, daya serap tenaga kerja pada industrikecil juga dipengaruhi oleh tingkat investasi dan volume produksi.

Selanjutnya tekhnik produksi yang digunakan diduga juga mempengaruhi tingkat efisiensi. Dikarenakan tingkat efisiensi berkenaan dengan biaya input dan nilai output maka biaya produksi, volume produksi dan harga produk juga mempengaruhi efisiensi. Faktor lainnya yang diidentifikasi memepgaruh efisiensi berkenaan dengan optimalisasi penggunaan tenaga kerja.Dimana, pengoptimalisasian tenaga kerja itu sendiri dipengaruhi oleh karakteristik biografi dan tingkat keahlian (skill) yang dimiliki tenaga kerja.Adapun karakteristik biografi tenaga kerja dapat diamati dari tingkat umur, pendidikan dan lama pengalaman bekerja pada bidangnya.Sedangkat tingkat keahlian tenaga kerja dipengaruhi oleh kursus atau pendidikan dan latihan yang pernah diikuti.

Terakhir untuk distribusi pendapatan diduga juga dipengaruhi oleh faktor teknik produksi.Hal ini dikarenakan teknik produksi cenderung mencerminkan jumlah tenaga kerja yang digunakan.Dismaping faktor tekhnik produksi, tingkat distribusi juga dipengaruhi oleh sistim dan tingkat upah yang berlaku.Yang dimaksud dalam hal ini berkenaan dengan tingkat intensif, bonus dan tunjangan yang diberikan.

Faktor-faktor yang telah diidentifikasi di atas merupakan identifikasi awal, yang terkait dengan penelitian ini. Namun demikian, diharapkan dapat membantu pengidentifikasian lebih lanjut dalam konteks yang lebih luas guna penelitian selanjutnya

2. Dinas Perindustrian dan Perdagangan, khususnya Dinas Perindustrian dan Perdagangan Kota Jambi perlu terus meningkatkan peranannya sebagai mediator guna pengembagan kerjasama yang terintegrasi antara industri kecil engan instansi yang terkait (Dinas Koperasi dan Pembinaan Pengusaha Kecil, Dinas Perindustrian dan Perdagangan serta 
pihak perbankan), selanjutnya Dinas Perindustrian dan Perdagangan juga harus mampu mengembangkan pola kemitraan antara industri kecil dengan Badan Usaha Miliki Swasta dan Badan Usaha Milik Negara. Pengembangan pola kemitraan yang dimaksud harus lebih bersifat komprehensif dan berkelanjutan. Dengan demikian diharapkan terjadi transfer kemampuan, mulai dari aspek manajemen dan produksi sampai pada aspek pemasaran. Hal ini akan berdampak pada perkembangan industri kecil yang efisien dan berdaya serap tenaga kerja.

Bagi Pemerintah Daerah perlu melakukan perumusan kebijakan yang bersifat kondusif bagi pengembangan industri kecil, terutama yang berkenaan degna peningkatan kemampuan daya serap tenaga kerja, tingkat efisiensi dan distribusi pendapatan. Secara lebih spesifik, keibjakan tersebut dapat berupa insentif keringanana pajak yang dikaitkan dengan produktivitas dan efisiensi, tingkat investasi yang dikaitkan dengan jumlah tenaga kerja minimal serta pengawasan secara konsisten dalam pelaksanaan Upah Minimum Regional

\section{DAFTAR PUSTAKA}

Abramomitz. 2005, Resources and Output Trends in The United State American Economic Reviem, Edisi Mei, USA

Agosin Manuel. R. 2006 Development Patterns and Labour Absortion in Colombian Manufacturing, The Jurnal of Development Studies Vol. 12 No. 4 Edisi Juli.

BPS. 2012. Kota Jambi Dalam Angka 2012, Biro Pusat Statistik Kota Jambi, Jambi

Branson, Willian. H. 2009. Macroeconomic Theory, Mc. Graw Hill, New York

Chu Chi S.Lin. 2005, Production Function Factor Substitusion, and Direct Foreign Invesment : A Case Study in Taiwan, Asian Economic Journal, Vol. 9 No. 2

Clague, Christoper K. 2006. Capital Labor Substitusion in Manufacturing in Under Development Countries, Jurnal Econometrica, Vol. 37 No. 3 Edisi Juli.

Dinas Perindustrian dan Perdagangan Kota Jambi, 2012.Laporan Tahunan 2012, Kantor Departemen Perindustrian dan Perdagangan Kota Jambi, Jambi

Ferguson, C.E dan Gould, J.P.1975.Microeconomic Theory, Richard D. Irwi Inc. Home Illionis. 